\title{
ACCELERATED WEATHERING TESTS OF SOLDERED AND TINNED SHEET COPPER
}

\author{
By Peter R. Kosting ${ }^{1}$
}

\begin{abstract}
The pitting and furrowing of tinned and soldered sheet copper, which sometimes happen when weathered, were duplicated in the laboratory by exposing the copper to a humid atmosphere, rich in $\mathrm{SO}_{2}$ and $\mathrm{CO}_{2}$ at $50^{\circ} \mathrm{C}$. or over. The progress of corrosion was followed by means of weight losses, tensile and bend tests. Extensive pitting and furrowing occurred only after the tinned and soldered specimens had been heated to high enough temperatures to cause the formation of complex copper-tin alloys. Furrowing reduced the strength of soldered joints and impaired markedly the fatigue properties of the copper as measured by the number of bends needed for failure.

Spilt flux may cause pitting of copper, but the pits thus formed occur under deposits of copper salts. A red deposit of cuprous oxide was found under these salt deposits if the copper originally was oxidized.
\end{abstract}

\section{CONTENTS}

I. Introduction

III. Experimental work

1. Materials

2. Apparatus

3. Experimental details .

(a) Tinned copper

(b) Soldered copper..... 370

IV. Results

1. Tinned copper

2. Soldered copper

V. Miscellaneous observations and discussion

1. Corrosion of copper

2. Pitting of tinned copper.... 376

3. Pitting of soldered copper

4. Seam corrosion

5. Fluxes.... 378

VI Conclusions 378

378
379

VII. Acknowledgments Ached bibliography

\section{INTRODUCTION}

The widespread use of copper for roofing purposes has revealed that improper manipulation of the material can bring about premature failure of the roof. In most instances the cause of failure is obvious, but occasionally it is not so. These occasionally unexplained failures have been the subject of joint investigation by the Copper and Brass Research Association and the Bureau of Standards.

1 Research associate for Copper and Brass Research Association. 
A typical case is illustrated by a sample of sheet copper which had been in service for 16 to 20 years as a valley (fig. 1) in the roof of a residence, and which was sent to the Bureau of Standards for examination. Marked furrowing was observed in the copper along the lower edge of the solder band at those portions not covered by the shingles. No localized corrosion of the copper had occurred along the upper edge, except in the areas where the flow of rain water was greatest. Pits extending through the solder into the copper had formed along the high ridge of the soldered lock seam. Evidence of included flux was obtained upon sectioning the seam. Cavity $D$ was found to be filled with liquid, probably flux; likewise, the underside of the seam gave indications that flux had been left in place, although there was no evidence of any deep-seated corrosion having occurred.

Inspection of another old copper roof in the same general geographical region, which is an industrial one and whose atmosphere is corrosive, revealed that the copper on the horizontal, vertical, and sloping parts of a portion of the roof was badly pitted along soldered seams, whereas elsewhere on the same roof there was no evidence of the slightest deterioration of the copper at the seams. The examination of many roofs in a large city where the number of industrial plants is unusually low showed that pitting of the solder is commonplace. The copper exposed at the bottom of such pits was observed to be bright in some cases, and in others covered with patina. In any recess where water could collect along the edge of the soldered seam, or at points where water flowed away from the edge of the soldered seam, the copper was usually leather brown in color, which was different from the predominating color of the sheet. However, furrowing was not found.

When a copper roof is pitted and has an appearance suggestive of wormholes penetrating through it, it seems reasonable to assume that the roof is of tinned copper. The failure of the tinned copper roof on the Library of Congress building in Washington, D. C., has been described by Merica (1). ${ }^{1} \quad$ A recent examination made of a specimen of tinned copper of thin gage used for the ornamental work showed as many as 92 pits in an area of a square centimeter after service lasting probably more than a quarter of a century. This is a tremendous increase over that reported before, (1) and is indicative of the influence of bending upon the weathering of tinned copper. Another pitted or "worm-eaten" roof, supposedly of copper, was found to be of tinned copper. The failure of copper roofing by pronounced pitting and furrowing seems quite often to be associated with tin or solder and is the subject of this investigation.

\section{PREVIOUS WORK}

It appears that no systematic study has been made of furrowing at copper-solder junctions. Merica (1) in his study of the failed tinned copper roofing showed that the tin combined with the copper to form phases known as $\epsilon^{\prime}$ and $\eta(2)$ which are cathodic to copper, hence, detrimental from the standpoint of corrosion resistance. Dafton and Brady (3) have reported that the corroded areas of tinned copper pipes are cathodic to copper. Lead-tin solder is considered

1 The figures given in parentheses here and throughout the text relate to the reference numbers in the selected bibliography given at the end of this paper. 


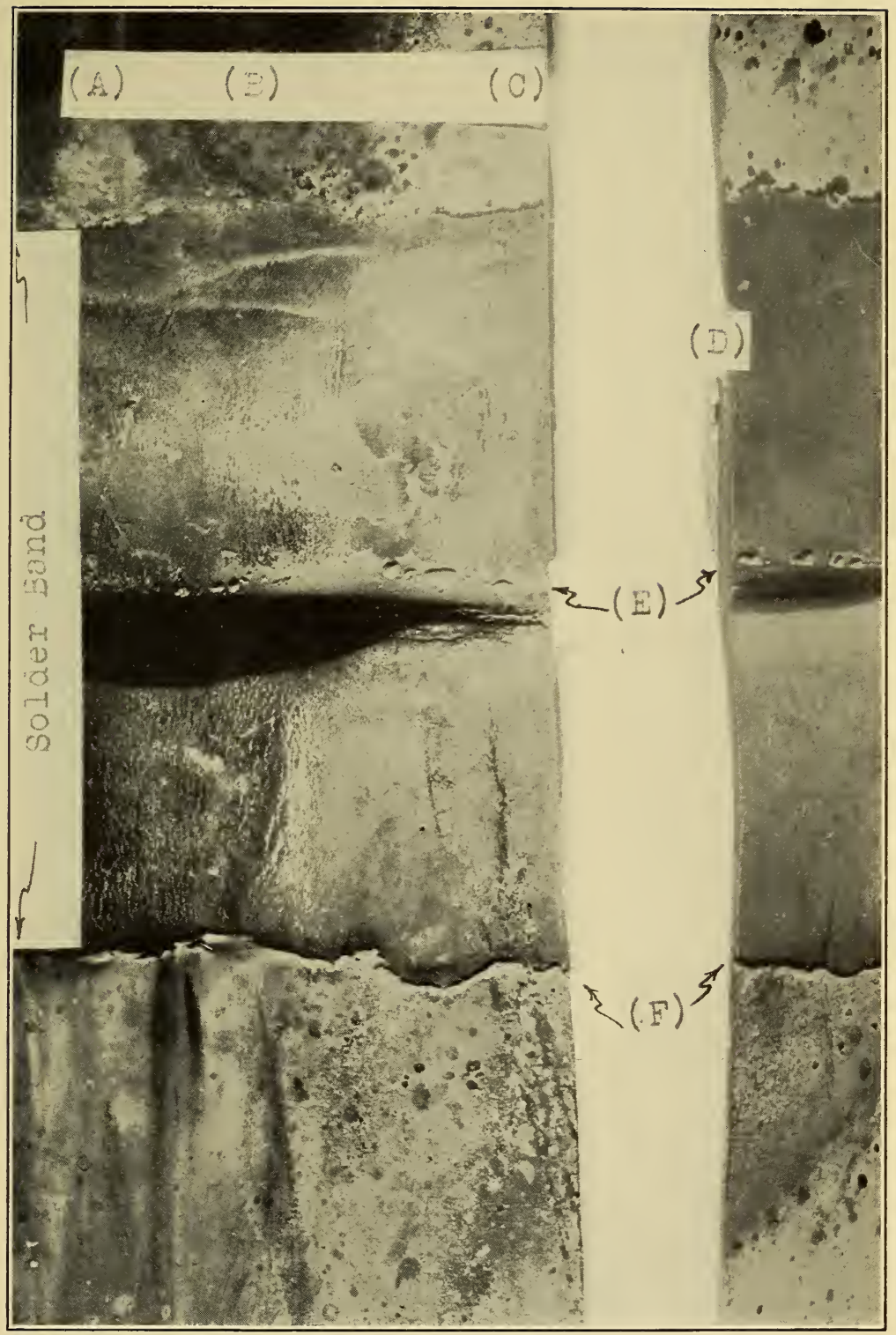

Figure 1.-Seam corrosion on soldered copper valley. $\quad \times 2$

$A$, Etched copper where flow of rain water was greatest; $B$, tarnished copper; $C$, patina covered copper where flow of rain water was least; $D$, hole of seam in which flux was trapped; $E$, pits extending through solder at high ridge of seam; $F$, furrow at copper-solder junction. 
as being anodic to copper. However, the current (4) set up due to galvanic action has been reported to be small and to decrease with time.

In a study of the metallurgy of soldered copper Crow (5) showed that at temperatures below $300^{\circ} \mathrm{C}$. the tin of eutectic solder (63 per cent $\mathrm{Sn}: 37$ per cent $\mathrm{Pb}$ ) combined with copper to form the $\epsilon^{\prime}$ phase. At temperatures as low as $325^{\circ} \mathrm{C}$. the $\eta$ phase was also formed and appeared as a blue band between the copper and $\epsilon^{\prime}$ layer when examined under a microscope. Weiss (6) obtained the $\delta$ bronze phase by holding copper in tin at $550^{\circ} \mathrm{C}$. for 24 hours, whereas at $400^{\circ} \mathrm{C}$. $\eta$ was the richest copper phase obtained.

The etching characteristics of the different copper-tin phases have been described by Heycock and Neville (7). Prolonged etching must be carried out to differentiate between them. Crow (5), Merica (1), and also other investigators have reported difficulty in etching.

\section{EXPERIMENTAL WORK}

\section{MATERIALS}

Sheet electrolytic copper, 16-ounce gage (nominally 0.0215 inch or $0.055 \mathrm{~cm}$ thick) and of roofing temper hardness, was used for the experiments with solder, which was made from equal parts, by weight, of lead and tin. The flux used was made by neutralizing hydrochloric acid (specific gravity 1.18) with zinc, filtering and adding $10 \mathrm{~g} / \mathrm{l}$ of ammonium chloride. For the work with tinned copper, commercially hand-tinned copper, electrotinned copper, and block tin were used. Table 1 lists the chemical compositions of these materials. The hand-tinned sheets had innumerable fine parallel scratches extending their full length.

TABLE 1.-Chemical composition of materials

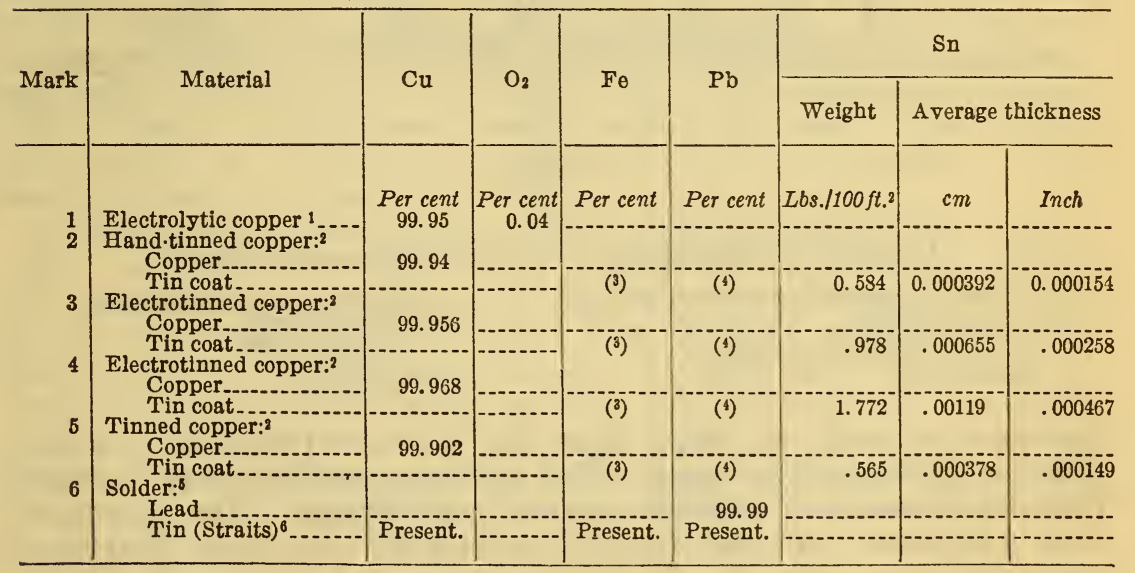

1 Manufacturer's analysis.

Analyses by American Brass Co.

Present but in negligible amount.

- Not detected.

Solder made from equal parts of lead and tin whose analyses are given.

- Spectroscopic analysis.

$99675-32-4$ 


\section{APPARATUS}

The accelerated weathering test (8) as used at the Bureau of Standards was utilized in the endeavor to duplicate in the laboratory the weathering of soldered and tinned copper. Figure 2 shows schematically the apparatus which was a modification of that described in the publication just referred to. An industrial atmosphere was simulated by passing a gaseous mixture consisting of 1 per cent $\mathrm{SO}_{2}, 5$ per cent $\mathrm{CO}_{2}, 94$ per cent air by volume, into the bottom of
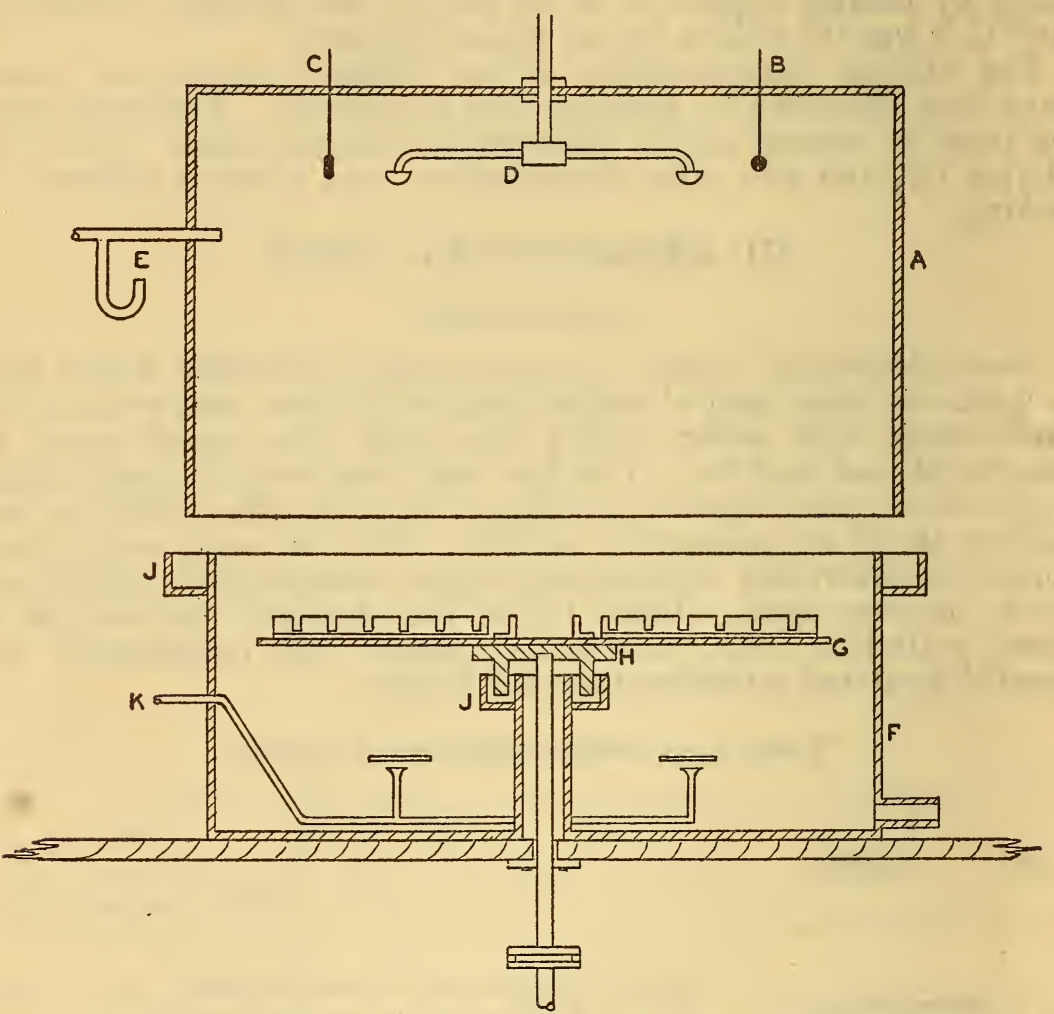

FIGURE 2.- Apparatus used in accelerated weathering test

\footnotetext{
$A$, upper and movable part of corrosion tank. $B$, thermometer

$C$, thermoregulator.

$D$, water-sprinkling arrangement.

$E$, gas outlet.
}

\author{
$F$, lower part of corrosion tank. \\ $G$, specimen rack. \\ $H$, rack coupling. \\ $J$, water seal. \\ $K$, gas inlet.
}

the corrosion tank, in which there was a layer of 4 inches $(10 \mathrm{~cm})$ of water maintained at the specified temperature by electric heaters. The atmosphere was thereby rendered very humid. The specimens were supported on the circular lead-coated aluminum platform, which could be rotated. The shower was used only in the initial tests.

Repeated immersion tests were carried out in equipment already described by Rawdon, Krynitsky, and Finkeldey $(9,10)$. Beij's (11) solution of $1 N$ sodium chloride and $0.6 N$ sulphurous acid was 
employed, evaporation losses being made up by additions of a concentrated sulphurous acid solution containing about $10 \mathrm{~g} \mathrm{SO}_{2}$ in $100 \mathrm{~g}$ water. The specimens were supported in glass stirrups and were dipped in the solution for about one-half minute every 15 minutes.

Salt spray tests were carried out. A 20 per cent solution of sodium chloride was atomized in an alberene box by using air at a pressure of $15 \mathrm{lbs} . / \mathrm{in} .^{2}\left(0.01 \mathrm{~kg} / \mathrm{mm}^{2}\right)$.

Bend tests were made in the machine developed by S. N. Petrenko, of the Bureau of Standards. In this apparatus the specimen was bent, while under tension, around a radius approximately twenty times its thickness, first $90^{\circ}$ in one direction and then $90^{\circ}$ in the reverse direction. The number of reversals to produce failure was counted.

An Amsler tensile testing machine of 400 pounds (180 kg) capacity was used for determining the tensile properties. Tension specimens with 2-inch $(5 \mathrm{~cm})$ gage length were made in accordance with specification E8-27T of the American Society for Testing Materials (1930), with the slight modification that the gradual taper from the ends of the reduced section left in the center a length of one-half inch whose width was 0.500 inch $(1.27 \mathrm{~cm})$. This allowed a little leeway in placing the copper-solder junction in the minimum reduced section of the test specimen.

\section{EXPERIMENTAL DETAILS}

(a) TINNED COPPER

Specimens, $10 \mathrm{~cm}$ (3.9 inches) square, of copper, tinned copper, and tinned copper from an old roof were used in the initial test with accelerated weathering. In these and subsequent tests the specimens were polished, washed, dried in alcohol and in ether, and weighed. On some sheets four parallel scratches were made deep enough to expose the copper. After being exposed to the corrosive atmosphere for five hours at $46^{\circ}$ to $50^{\circ} \mathrm{C}$., the specimens were showered with cold water for one hour. Some specimens were scrubbed with a bristle brush between cycles; others were not. After drying and standing in a desiccator for 18 hours they were weighed before being exposed in the next cycle.

A second series of tests was carried out with soft electrolytic copper, highly polished electrolytic copper, block tin, hand-tinned copper, and electrotinned copper having nominally 1 pound and 2 pounds tin per 100 square feet or 0.00026 inch $(0.00066 \mathrm{~cm})$ and 0.00052 inch $(0.0013 \mathrm{~cm})$ thick, respectively, on each side. The electrotinned copper specimens were tested in the "as received" condition as well as after heating to $350^{\circ} \mathrm{C}$. and to $500^{\circ} \mathrm{C}$. The same testing procedure was followed, except that a temperature of $50^{\circ} \mathrm{C}$. was maintained, and the specimens were scrubbed between successive cycles. They were weighed at the end of the tenth, twentieth, and thirtieth cycles.

Before testing, all the specimens with the exception of the polished copper ones were rubbed down with No. 000 emery paper. The progress of corrosion was followed by determining the changes in weight and by noting the depth of the pits. Since the same pit 
could not be located every time, a number of pits were measured and the maximum depth recorded. The number of pits per unit of area, revealing copper at a magnification of $\times 6$, was counted at each of the four corners of the specimen by means of a template having a square hole $0.5 \mathrm{~cm}$ (0.2 inch) on edge.

\section{(b) SOLDERED COPPER}

Preliminary work showed that seam corrosion could be duplicated in the same testing apparatus. Copper soldered with half and half solder showed furrowing after accelerated weathering, regardless of whether acid flux or a commercial noncorroding flux was used. Pitting through the solder occurred wherever the solder was thin. Strips of electrolytic copper, 8 by $20 \mathrm{~cm}$ (3 by 8 inches), were dipped in flux and then in molten solder which was kept at $270^{\circ} \mathrm{C}$. in a nichrome-wire wound carbon block trough $15 \mathrm{~cm}$ (6 inches) deep. The drop in temperature during the 1-minute soldering period did not exceed $5^{\circ}$. Some specimens of plain and soldered copper were annealed at $500^{\circ} \mathrm{C}$. under charcoal for three hours and then air cooled.

After being rubbed down with No. 0 emery paper, washed, dried, and weighed, sets of specimens were acceleratedly weathered for 200 hours at $40^{\circ}$ C., 200 hours at $50^{\circ}$ C., and 90 hours at $60^{\circ} \mathrm{C}$. They were removed from the corrosion tank twice a day, at the end of runs whose duration was alternately $6 \frac{1}{2}$ and $16 \frac{1}{2}$ hours, sprayed with hot water for five minutes, allowed to dry, and then replaced. This procedure did not as seriously alter the testing conditions within the tank as above described (p. 369) and allowed corrosion to be continued throughout the entire day ( 24 hours). At the end of every 100 hours the specimens were scrubbed with a bristle brush and water and reweighed. After being weighed at the end of 200 hours' exposure they were reweighed after being given five half-minute dips in 15 per cent (by weight) sulphuric acid, which removed all products of corrosion without appreciably attacking the uncorroded portions.

Strips for tensile and bend tests were cut from these acceleratedly weathered specimens. Determinations were made of the ultimate tensile strength, per cent elongation in 2 inches $(5 \mathrm{~cm})$ of which 1 inch $(2.5 \mathrm{~cm})$ was soldered copper, and the number of reversals to produce failure when under tensions of 4,000 and 1,000 pounds per square inch" $\left(2.8\right.$ and $\left.0.70 \mathrm{~kg} / \mathrm{mm}^{2}\right)$.

The specimens for metallographic examination were first copperplated and then mounted for polishing in one of the following: Wood's metal, Canadian balsam, tin, and half-and-half solder. Oblique surface sections were obtained by slightly bending the specimen before mounting and polishing on the convex side (1). An etching reagent of ammonium hydroxide and hydrogen peroxide was used for revealing the structure of the copper, and an acid ferric chloride solution, as well as nitric acid with chromium oxide additions, for revealing the structure of the coating. The galvanic action between the copper and the coating interfered with uniform etching. Polishing was difficult on account of the gouging out of the soft coating. 


\section{RESULTS}

\section{TINNED COPPER}

The appearance of the specimens of hand-tinned copper after accelerated weathering was somewhat comparable with that after outdoor weathering, the surface being dulled and discolored, often with a greenish tinge. The discolored areas were plainly etched and pitted. The greatest corrosive attack occurred along the multitude of fine scratches. No marked peculiarity was noticed on the deep scratches which revealed copper. The specimens with the thinnest tin coat suffered the most corrosion, as judged both by appearances and losses in weight. The specimens of the old tinned copper roofing, which were included in the test, showed very high corrosion rates. Table 2 lists the results of this initial test. The losses in weight are given in $\mathrm{g} / \mathrm{dm}^{2} /$ cycle for the first, fifth, and tenth cycles, as well as the average for the 10 cycles. The time required till the first appearance of copper through the coating in areas away from the edge of the specimen was taken as the time of failure.

TABLE 2.-Initial accelerated weathering test of tinned sheet copper

AS RECEIVED

Scrubbed after each cycle

\begin{tabular}{|c|c|c|c|c|c|}
\hline \multirow[b]{2}{*}{ Specimen } & \multicolumn{4}{|c|}{ Corrosion rate $-\mathrm{g} / \mathrm{dm}^{2} /$ cycle } & \multirow{2}{*}{$\begin{array}{l}\text { Time to fail } \\
\text { (cycle num- } \\
\text { ber) }\end{array}$} \\
\hline & $\begin{array}{l}\text { First } \\
\text { cycle }\end{array}$ & $\begin{array}{l}\text { Fifth } \\
\text { cycle }\end{array}$ & $\begin{array}{l}\text { Tenth } \\
\text { cycle }\end{array}$ & $\begin{array}{l}\text { A verage } \\
\text { of } 10 \\
\text { cycles }\end{array}$ & \\
\hline $\begin{array}{l}5-1 \ldots \\
5-2 \ldots \\
5-3 \ldots\end{array}$ & $\begin{array}{r}0.0001 \\
.0002 \\
.0000\end{array}$ & $\begin{array}{r}0.0050 \\
.0038 \\
.0019\end{array}$ & $\begin{array}{l}0.0020 \\
.0021 \\
.0018\end{array}$ & $\begin{array}{l}0.0020 \\
.0020 \\
.0016\end{array}$ & $\begin{array}{l}\text { Fifth. } \\
\text { Fourth. } \\
\text { Fifth. }\end{array}$ \\
\hline
\end{tabular}

Not scrubbed after each cycle

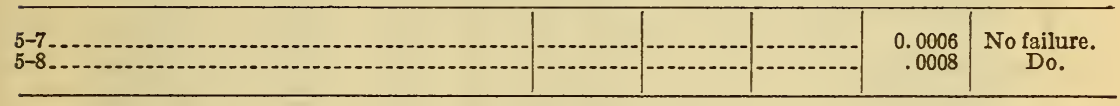

SCRATCHED SPECIMENS

Scrubbed after each cycle

\begin{tabular}{|c|c|c|c|c|c|}
\hline 5-6 & $\begin{array}{r}0.0002 \\
.0001 \\
.0003\end{array}$ & $\begin{array}{r}0.0011 \\
.0047 \\
.0090\end{array}$ & $\begin{array}{r}0.0020 \\
.0026 \\
.0045\end{array}$ & $\begin{array}{r}0.0013 \\
.0020 \\
.0048\end{array}$ & $\begin{array}{l}\text { No failure. } \\
\text { Fifth. } \\
\text { Fourth. }\end{array}$ \\
\hline
\end{tabular}

Not scrubbed after each cycle

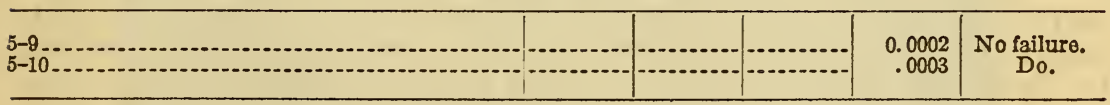

Tinnod copper from old roof

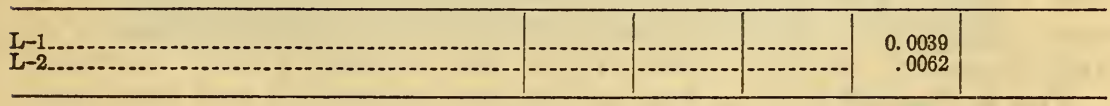


It was difficult to obtain duplicate corroding conditions within the tank from one run to the next. This can be attributed in part to the use of the cold-water shower, which immediately removed all traces of sulphur dioxide gas from the atmosphere. It was known that considerable time was required before the composition of the gas mixture within the tank became uniform.

Table 3 lists the results obtained from the second accelerated weathering test. The adherent films which formed on the copper were slightly soluble in water but were removable only by pickling. The presence of copper ions and sulphate ions was detected in the wash water used in scrubbing the specimens. Under the microscope, green specks were discernible on the surface of the scrubbed copper, but the general appearance was dark brown or black. Green patina formed in time, especially on the specimens not scrubbed between cycles.

TABLE 3.-Second accelerated weathering test of plain and tinned sheet copper

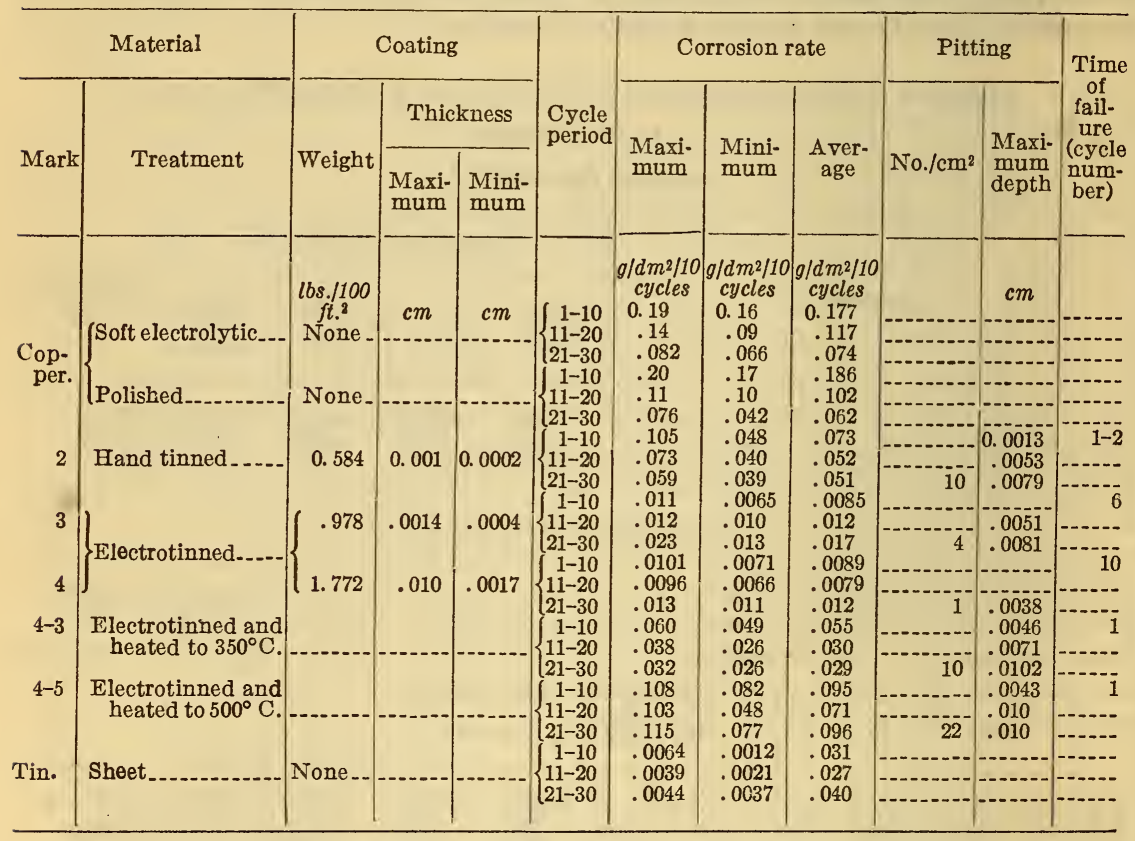

Visual observation showed that thin oxide films on copper, such as are formed when the copper is heated at $100^{\circ} \mathrm{C}$., tended to retard corrosion during the initial periods of weathering. However, thicker films did not show this tendency, probably on account of their cracking. In Table 5 it is shown that the oxide films of negligible weight produced at $130^{\circ}, 170^{\circ}$, and $500^{\circ} \mathrm{C}$. were accompanied by greater corrosion losses. The set of specimens which was weathered at $60^{\circ} \mathrm{C}$. was oxidized for a longer period of time than that weathered at $50^{\circ} \mathrm{C}$. and, therefore, having a thicker oxide film, suffered greater corrosion.

The surface of the hand-tinned copper was dulled and discolored. all had long, parallel, brown or yellow streaks speckled with black; 


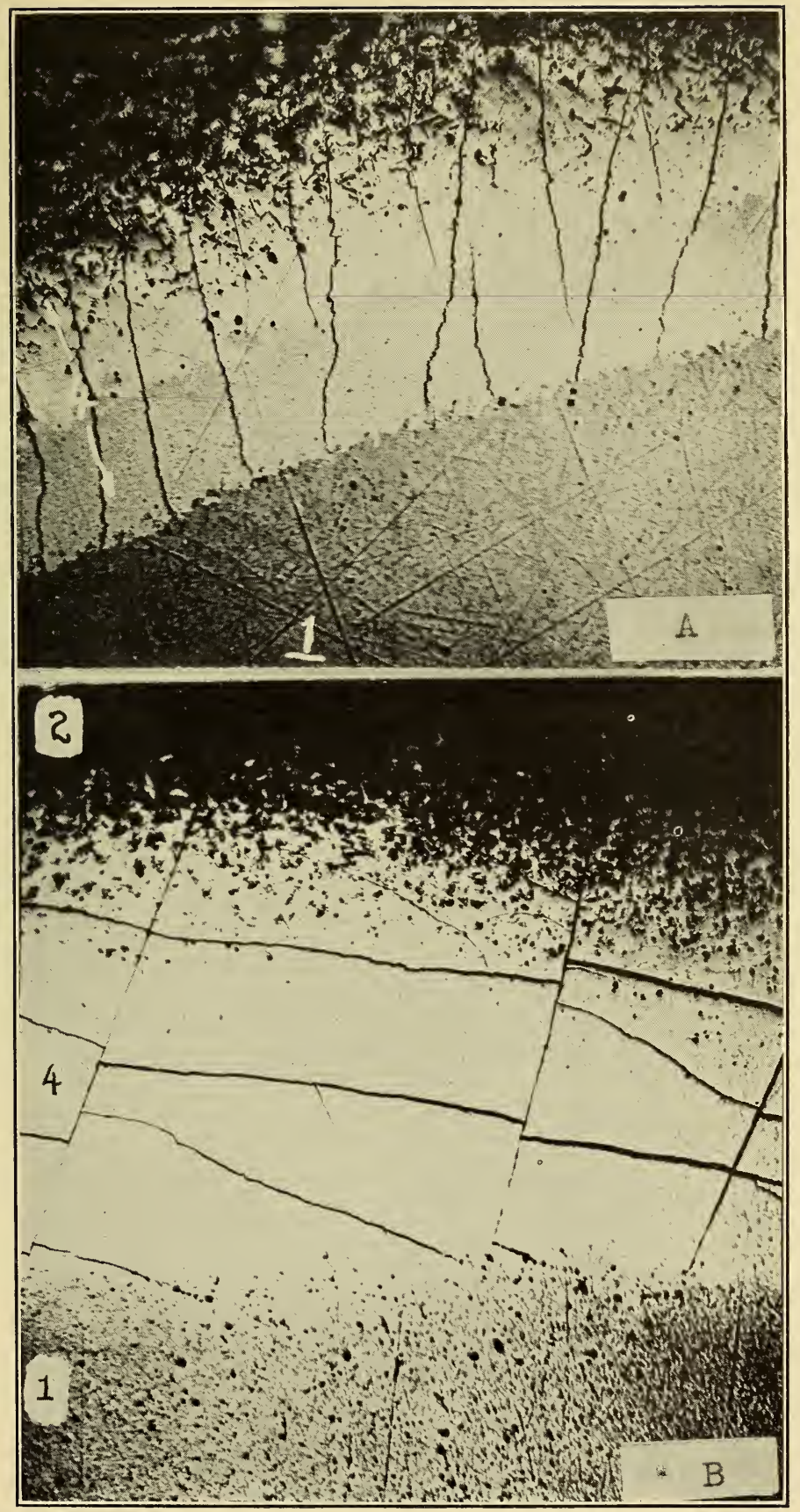

Figure 3.-Oblique sections of heat treated electrotinned sheet copper showing cracks in coating. $\times 100$

$A$, Heated to $350^{\circ} \mathrm{C}$.; $B$, heated to $500^{\circ} \mathrm{C}$. 1 , Sheet copper base; 2 , unchanged tin; 4 , copper-tin alloys. Both unetched. 
B. S. Journal of Research, RP422

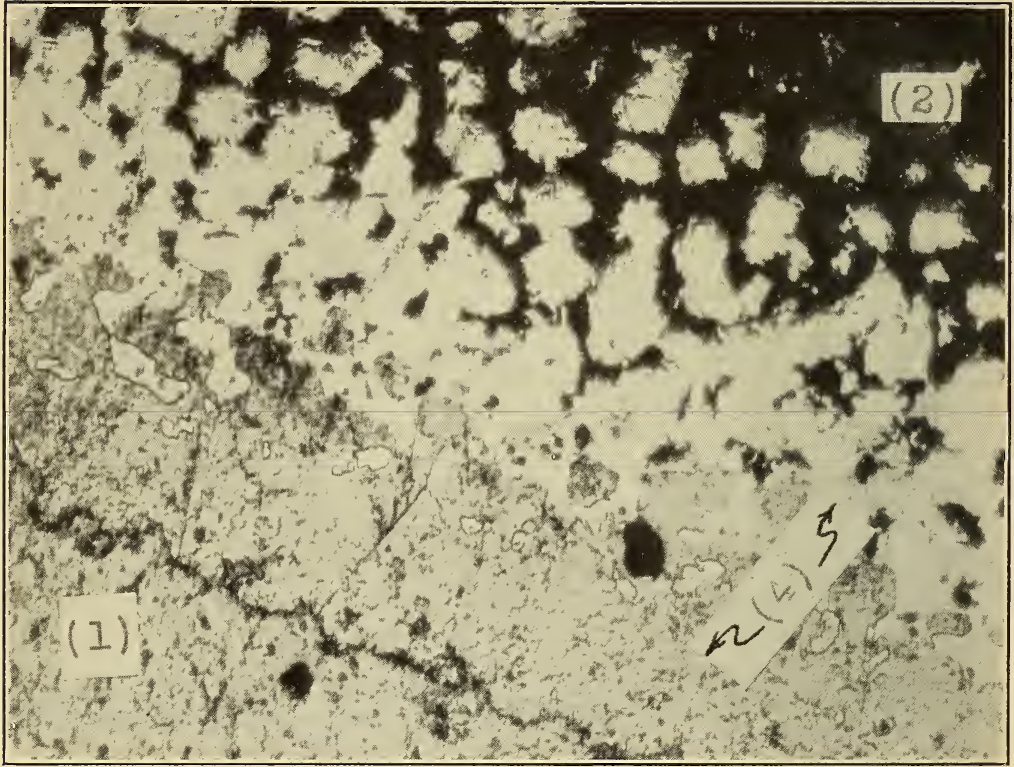

FIgURE 4.-Oblique section of electrotinned sheet copper heated to $350^{\circ} \mathrm{C}$. for three hours. $\times 500$

Etchant: Nitric acid. 1, Sheet copper base; 2, unchanged tin; 4, copper-tin alloys. 
Accidental scratches were badly discolored. Electrotinned copper was stained considerably but was not streaked like the hand-tinned copper. It resembled the sheets of block tin. Considerable edge corrosion occurred, the tin being removed. The failure of the coating was greatly facilitated by the heating of electrotinned copper to a temperature above the melting point of the tin, the appearance of the pitted areas being similar to that of the old out-doors-weathered tinned copper. The specimens of block tin were tarnished and speckled with dark and light brown spots. The indications were that its corrosion rate tended to increase with time.

The microstructure of the coatings on heat-treated electrotinned copper was rather complex. Electrotinned copper had but one phase present in the coating - the tin. Upon heating to $350^{\circ}$ and $500^{\circ} \mathrm{C}$., the copper and tin alloyed, copper dissolving quite rapidly in the tin. The alloy layers were brittle and slight bending caused them to crack, as shown in Figure 3. Many of these cracks extended through the alloy layer only. During polishing a slight relief effect was sometimes obtained, as shown in Figure $3(a)$, thus revealing the complex nature of the coating.

At least two phases were distinguishable in the alloy layer formed at $350^{\circ} \mathrm{C}$. In Figure 4 , next to the copper is a dove gray layer, and next to it is a brilliantly white layer. Patches of unchanged tin etched dark. Particularly good contrast was obtained in this figure by leaving the specimen over night in the laboratory a tmosphere.

By heating to $500^{\circ} \mathrm{C}$. another phase was formed which tarnished brownish on etching. This phase and the dove gray and brilliant white phases noted above are to be seen in Figure 5. In one place only, not shown, was the needlelike structure with a brilliant white fringe found to have a definitely blue color, characteristic of the $\eta$ phase. It is assumed that the brownish phase is $\delta$, the brilliant white $\epsilon^{\prime}$ and the dove gray $\eta$.

The salt spray test appears to be a very slow method for producing failure of tin coating on copper. After 1,000 hours' exposure, only a slight difference between handtinned and electrotinned specimens was noticeable, the former showing spots of bare copper and the latter not. The time of the first appearance of these bare spots could not be determined.

\section{SOLDERED COPPER}

In Tables 4 and 5 and in Figure 6 are given the results of accelerated weathering of soldered copper. At the end of the first 100-hour period many of the specimens were found, after scrubbing, drying, and weighing, to have increased in weight, and after 200 hours very slight losses were noticeable. However, after removing the corrosion film by pickling considerable loss in weight was observed. The reported corrosion rates for soldered copper were calculated on the assumption that all the loss was from the bare copper portion whose area was very nearly 50 per cent of the total area exposed. These figures indicate that the corrosion rate of soldered copper increased with increase in annealing temperature to which the solder was subjected. 
TABLE 4.-Tensile properties of plain and soldered sheet copper before and after accelerated weathering

\begin{tabular}{|c|c|c|c|c|c|c|c|c|c|}
\hline \multirow{3}{*}{ Mark } & Material & \multicolumn{2}{|c|}{$\begin{array}{l}\text { Before weath- } \\
\text { ering }\end{array}$} & \multicolumn{6}{|c|}{ After weathering } \\
\hline & \multirow{2}{*}{ Treatment } & \multirow{2}{*}{$\begin{array}{l}\text { Tensile } \\
\text { strength }\end{array}$} & \multirow{2}{*}{$\begin{array}{l}\text { Elon- } \\
\text { gation }\end{array}$} & \multicolumn{2}{|c|}{$\begin{array}{c}200 \text { hours at } \\
40^{\circ} \mathrm{C} \text {. }\end{array}$} & \multicolumn{2}{|c|}{$\begin{array}{c}200 \text { hours at } \\
50^{\circ} \mathrm{C} \text {. }\end{array}$} & \multicolumn{2}{|c|}{$\begin{array}{l}90 \text { hours at } \\
60^{\circ} \mathrm{C} \text {. }\end{array}$} \\
\hline & & & & $\begin{array}{c}\text { Tensile } \\
\text { strength }\end{array}$ & $\begin{array}{l}\text { Elon- } \\
\text { gation }\end{array}$ & $\begin{array}{l}\text { Tensile } \\
\text { strength }\end{array}$ & $\begin{array}{c}\text { Elon- } \\
\text { gation }\end{array}$ & $\begin{array}{c}\text { Tensile } \\
\text { strength }\end{array}$ & $\begin{array}{l}\text { Elon- } \\
\text { gation }\end{array}$ \\
\hline \multirow{2}{*}{$\begin{array}{ll}1 & \mathrm{Cu} \\
1 & \mathrm{Cu} \\
1 & \mathrm{Cu} \\
1 & \mathrm{Cu}\end{array}$} & $\begin{array}{l}\text { Roofing temper } \\
\text { Annealed at } 500^{\circ} \mathrm{C} \\
\text { Soldered. }\end{array}$ & $\begin{array}{c}\text { Lbs./in. }{ }^{2} \\
32,900 \\
32,000 \\
32,800\end{array}$ & $\begin{array}{r}\text { Per cent } \\
41 \\
40 \\
37\end{array}$ & $\begin{array}{c}\text { Lbs./in. }^{2} \\
31,700 \\
32,400 \\
32,700\end{array}$ & $\begin{array}{c}\text { Per cent } \\
36 \\
43 \\
38\end{array}$ & $\begin{array}{c}\text { Lbs./in. }{ }^{2} \\
32,200 \\
31,500 \\
32,700\end{array}$ & $\begin{array}{c}\text { Per cent } \\
39 \\
35 \\
36\end{array}$ & $\begin{array}{c}\text { Lbs./in. }^{2} \\
33,200 \\
32,300 \\
32,800\end{array}$ & $\begin{array}{r}\text { Per cent } \\
39 \\
39 \\
36\end{array}$ \\
\hline & $\begin{array}{l}\text { Soldered and annealed at } \\
500^{\circ} \mathrm{C}\end{array}$ & 32,300 & 33 & 32,300 & 29 & 31,000 & 23 & 31,600 & 24 \\
\hline
\end{tabular}

NOTE.-All figures are average of three determinations.

TABLE 5.-Weight losses of plain and soldered sheet copper when subjected to accelerated weathering

\begin{tabular}{|c|c|c|c|c|c|c|c|c|c|c|}
\hline & Material & & & & eight los & $\mathrm{s}\left(\mathrm{g} / \mathrm{dm}^{2}\right.$ & of coppe & & & \\
\hline & & $200 \mathrm{~h}$ & ours at 4 & $0^{\circ} \mathrm{C}$. & $200 \mathrm{~h}$ & ours at 5 & ${ }^{\circ} \mathrm{C}$ & $90 \mathrm{hc}$ & urs at 60 & ${ }^{\circ} \mathrm{C}$. \\
\hline NHata & 1неандын & $\begin{array}{l}\text { Maxi- } \\
\text { mum }\end{array}$ & $\begin{array}{l}\text { Mini- } \\
\text { mum }\end{array}$ & $\begin{array}{c}\text { Aver- } \\
\text { age }\end{array}$ & $\begin{array}{l}\text { Maxi- } \\
\text { mum }\end{array}$ & $\begin{array}{l}\text { Mini- } \\
\text { mum }\end{array}$ & $\begin{array}{c}\text { Aver- } \\
\text { age }\end{array}$ & $\begin{array}{l}\text { Maxi- } \\
\text { mum }\end{array}$ & $\begin{array}{l}\text { Mini- } \\
\text { mum }\end{array}$ & $\begin{array}{c}\text { Aver- } \\
\text { age }\end{array}$ \\
\hline $\begin{array}{ll}1 & \mathrm{Cu} \\
1 & \mathrm{Cu} \\
1 & \mathrm{Cu} \\
1 & \mathrm{Cu}\end{array}$ & $\begin{array}{l}\text { Roofing temper } \\
\text { Annealed at } 500^{\circ} \text { C... } \\
\text { Soldered } \\
\text { Soldered and an- }\end{array}$ & $\begin{array}{l}0.36 \\
.35 \\
(.43)\end{array}$ & $\begin{array}{l}0.27 \\
.30 \\
(.21)\end{array}$ & $\begin{array}{l}0.30 \\
.33 \\
(.31)\end{array}$ & $\begin{array}{l}0.574 \\
.807 \\
(.567)\end{array}$ & $\begin{array}{l}0.465 \\
.624 \\
(.548)\end{array}$ & $\begin{array}{l}0.53 \\
.72 \\
(.56)\end{array}$ & $\begin{array}{l}0.55 \\
.57 \\
(.60)\end{array}$ & $\begin{array}{l}0.52 \\
.54 \\
(.57)\end{array}$ & $\begin{array}{l}0.54 \\
.56 \\
(.59)\end{array}$ \\
\hline $1 \mathrm{Cu}$ & $\begin{array}{r}\text { nealed at } 500^{\circ} \mathrm{C}- \\
\text { surface oxidized at- } \\
130^{\circ} \mathrm{C} . \\
170^{\circ} \mathrm{C} \\
500^{\circ} \mathrm{C}\end{array}$ & $(.37)$ & (. 33) & $(.36)$ & .997 & $(.912)$ & $\begin{array}{l}(.92) \\
.51 \\
.58 \\
.89\end{array}$ & $\begin{array}{l}(.77) \\
.70 \\
.64\end{array}$ & $\begin{array}{l}(.77) \\
.64 \\
.64\end{array}$ & $\begin{array}{l}(.77) \\
.67 \\
.64\end{array}$ \\
\hline
\end{tabular}

NотE.-Figures in parentheses were calculated on the assumption that all weight lost was from the bare copper portion whose area was measured and which was very nearly 50 per cent of total area exposed.

The physical appearance of the specimens after corrosion is shown in Figures 7 to 10 . Figure 9 is a magnified view of the furrowing which is especially in evidence in the A specimen; the B specimen shows, on the other hand, very slight attack.

After weathering, three phases were distinguished on these soldered and annealed specimens. Figure 10 shows the appearance of these phases and illustrates the association of pits with them. Areas C and $B$ are evidently the $\delta$ and $\eta$ phases and A the unchanged solder.

The characteristic microstructures of the soldered specimens are shown in Figures 11 to 13 . Figure 12 shows the cracks in the very thick coating of copper-tin alloys on soldered and annealed copper. The black line between the copper and the alloys resulted from the deep etching of the copper, which is anodic to the coating in ammonium hydroxide.

The repeated immersion tests did not exactly duplicate the furrowing of copper at copper-solder junctions. After 200 hours a plain copper specimen was coated with a uniform green film except at points of contact with the glass stirrups and at the bottom, which had a knife-blade edge. The solder of soldered-copper specimens was 
B. S. Journal of Research, RP422

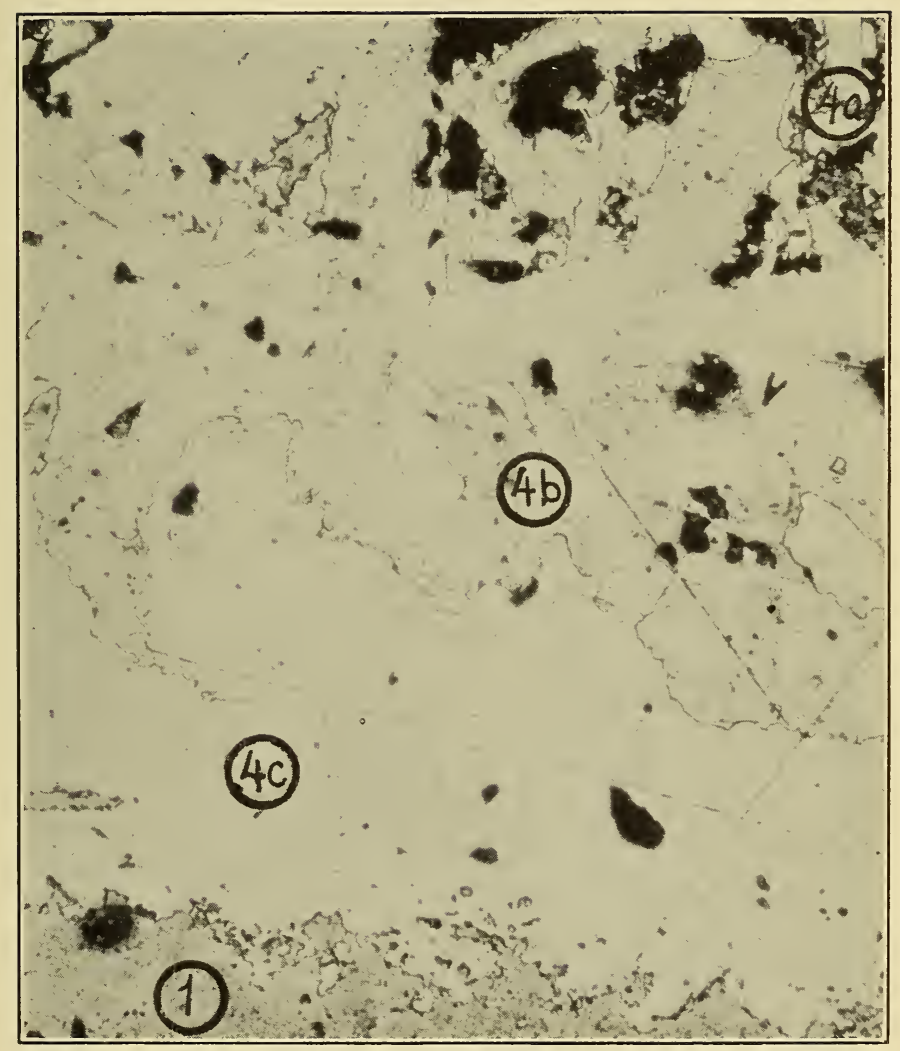

FIGURE 5.-Oblique section of electrotinned sheet copper heated to $500^{\circ}$ C. for 3 hours. $\times 200$

Etchant: Concentrated nitric acid. 1 , Sheet copper base; $4 a$, brilliant white $\epsilon^{\prime}$ phase; $4 b$, bluish $\eta$ phase; $\{c$, brownish $\delta$ phase. 


\section{B. S. Journal of Research, RP422}

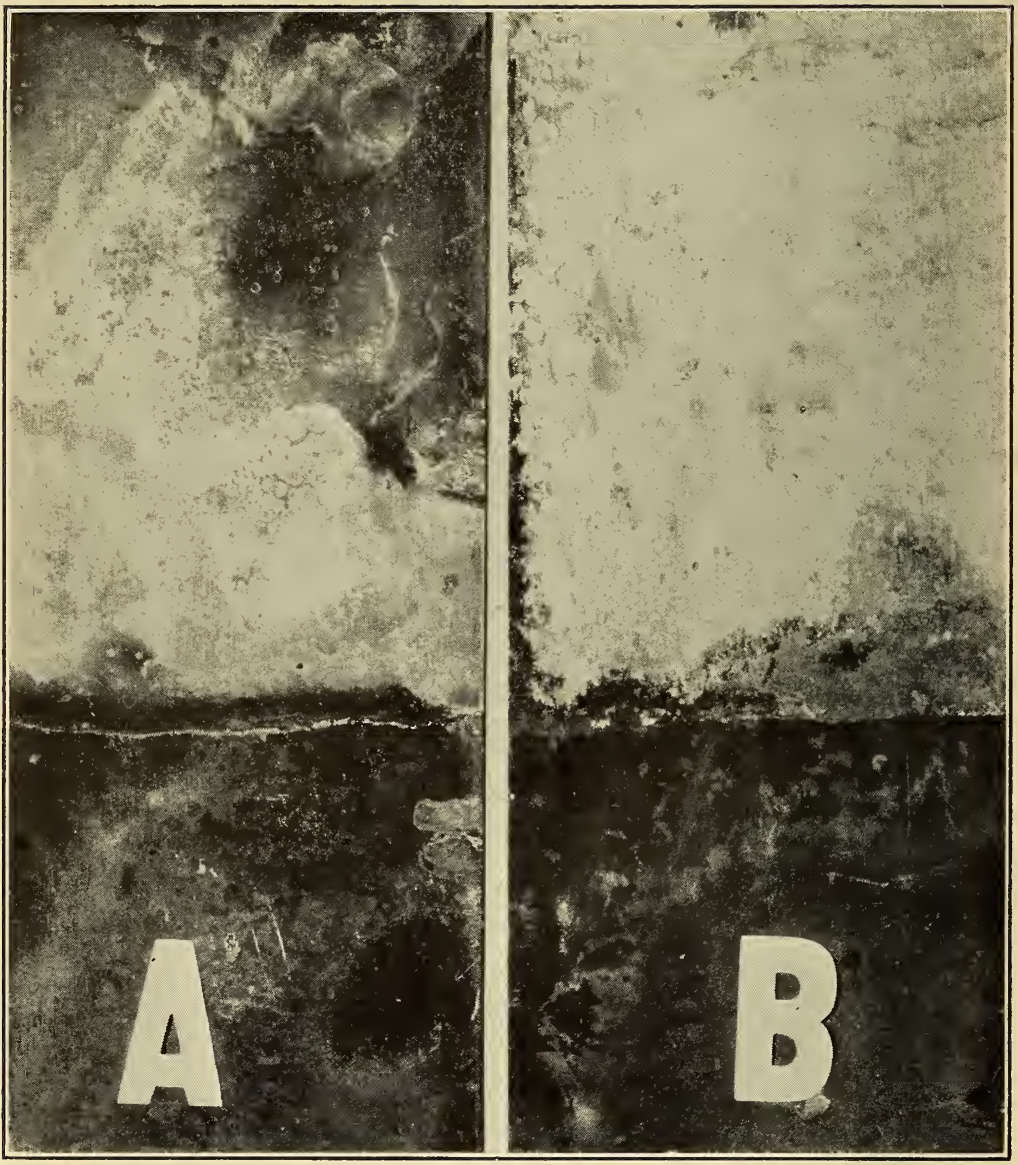

FIGURE 7.-Seam corrosion after 100 hours accelerated weathering at $50^{\circ} \mathrm{C} . \quad \times 0.7$

The surface has been scrubbed with bristle brush and water. $A$, Soldered at $270^{\circ} \mathrm{C}$. and heated to $500^{\circ} \mathrm{C}$.; $B$, soldered at $270^{\circ} \mathrm{C}$. Lower half is copper, upper half is solder covered 
badly corroded and did not appear to have accelerated the corrosion of the copper. However, copper soldered at $270^{\circ} \mathrm{C}$. and annealed at $500^{\circ} \mathrm{C}$. was badly attacked. There was no marked evidence of furrowing at the copper-solder junction as is obtained in accelerated weathering, but the copper was uniformly dissolved away. This left a pronounced shoulder at the junction. The soldered-covered portion was badly pitted and perforated. The pits had white walls and were always to be found in light-blue areas. Most of the solder had been dissolved away.

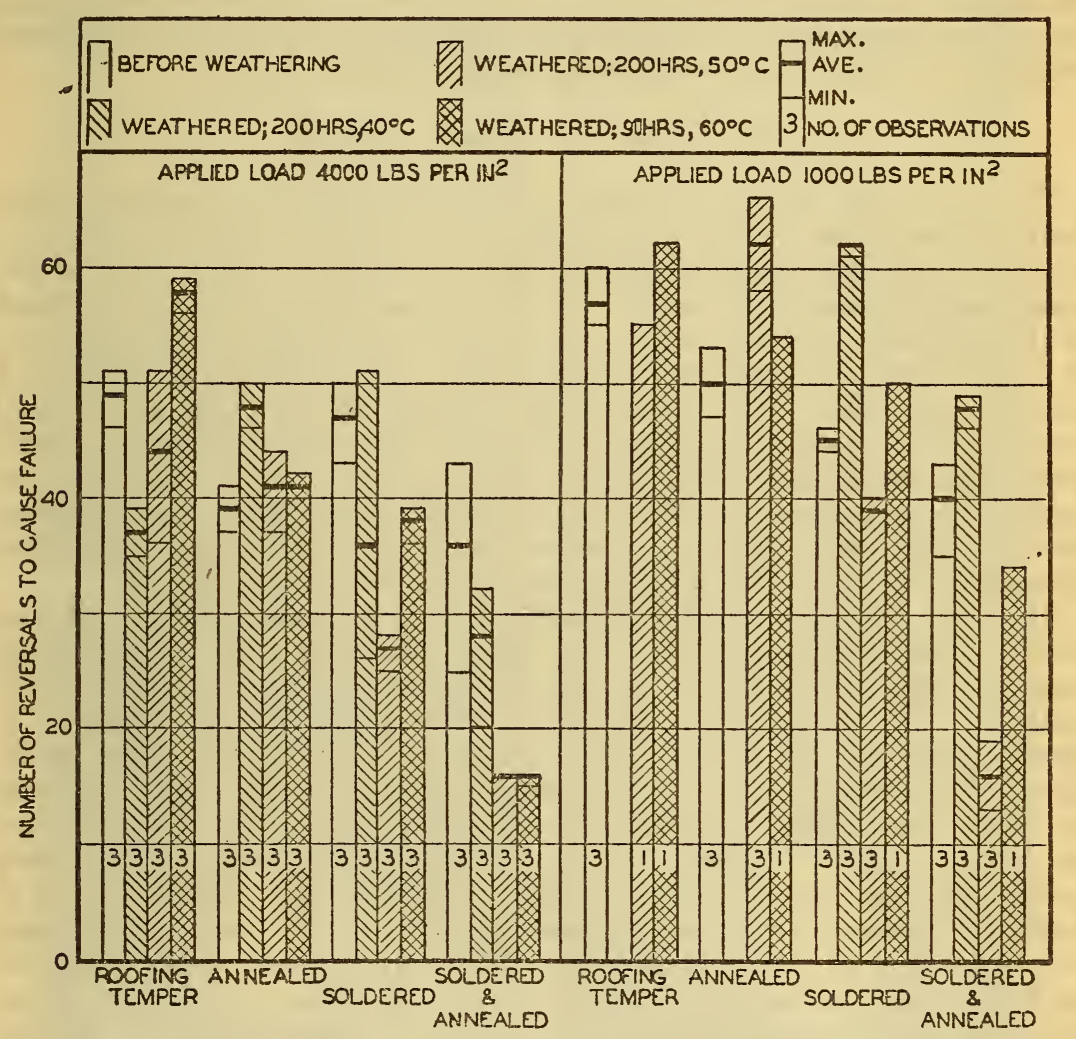

FrgURE 6.-Results of bend tests of plain and soldered sheet copper

\section{MISCELLANEOUS OBSERVATIONS AND DISCUSSION}

\section{CORROSION OF COPPER}

English investigators (12) of the atmospheric corrosion of copper have shown that copper sulphate is a common corrosion product found on copper roofs. The finding in these laboratory tests, reported herein, of water-soluble corrosion products with traces of the sulphate ion is consistent with Vernon's observations.

Intercomparisons of the corrosion rates of copper given in Tables 3 and 5 show that after 30 cycles or 150 hours of exposure to the gas mixture, copper lost a total of $0.368 \mathrm{~g} / \mathrm{dm}^{2}$, equivalent to a loss of $0.47 \mathrm{~g} / \mathrm{dm}^{2}$ in 190 hours. This is comparable with $0.53 \mathrm{~g} / \mathrm{dm}^{2}$ for 
copper of similar temper when continuously exposed to the corroding gas at $50^{\circ}$ for 200 nominal hours, of which actually 10 hours were used for washing and drying outside of the tank. Average penetration figures equivalent to these corrosion rates are $0.00053 \mathrm{~cm}$ and $0.00060 \mathrm{~cm}$, respectively. If 0.0001 inch $(0.00025 \mathrm{~cm})$ per year be taken as an average outdoor corrosion rate of copper $(13,14,15,16)$ then 200 hours continuous accelerated weathering approximates two years natural weathering. This agrees qualitatively at least with the fact that the depth of furrowing after accelerated weathering is not so great as outdoor weathering for 16 to 20 years. These comparisons are only approximate because weathering is governed by many factors which may alter the above considerations tremendously.

\section{PITTING OF TINNED COPPER}

The behavior of tinned copper during accelerated weathering fits fairly closely the description as given in the literature $(1,17,18)$. However, whether as marked furrowing or actual perforation of the sheet would occur is doubtful because of the marked chemical attack of the coating which occurred. On a roof the corrosion of the coating is so slow that the galvanic action between it and the copper has a long time in which to act and cause pitting, but in these accelerated tests the coating had an appreciable corrosion rate and consequently was removed before pronounced pitting could occur. An attempt was made to reduce this chemical corrosion by lowering the temperature of test, but difficulties due to the greater solubility of sulphur dioxide in water at the lower temperature were encountered.

It is the formation of brittle alloy layers between the copper and the tin that leads to pitting. The alloy layer is of greater complexity and is more brittle with increase in the temperature used while coating. Slight handling of tinned sheets would be sufficient to form cracks in the alloy layer, especially if the layer were thick. Scratches formed under circumstances that do not smear the soft tin along their walls would facilitate marked furrowing. As suggested by Merica, these coatings afford only mechanical protection. They have high corrosion rates as might be judged from Tables 2 and 5 , but the moment copper is exposed adjacent to the alloy, a galvanic cell is formed in the presence of an electrolyte; the copper is anodic and corrodes and so protects the alloy. The pits and furrows can grow in diameter and width by the coating being undercut, leaving the brittle alloy unprotected and thus subject to further corrosion.

The incompleted preliminary studies of the polarity of these alloys with respect to copper showed that in agitated solutions the copper was anodic to the different phases present in the tin coat and exposed by corrosion. This is in accordance with the observations of Merica, especially in sulphate solutions. Examination of the roof of the Library of Congress revealed that the furrows and pits were much larger on the dome roofing than on small pieces of tinned copper that had fallen from ornaments and lain for an indefinite period on flat portions of the roof. It should be expected that the difference in velocity between rain water flowing down over the dome and that flowing over the loose pieces lying on the flat roof would be considerable. Comparison with the tinned copper of flat decks on the roof was not possible because the roof had been painted. In Figure 1 
B. S. Journal of Research, RP422

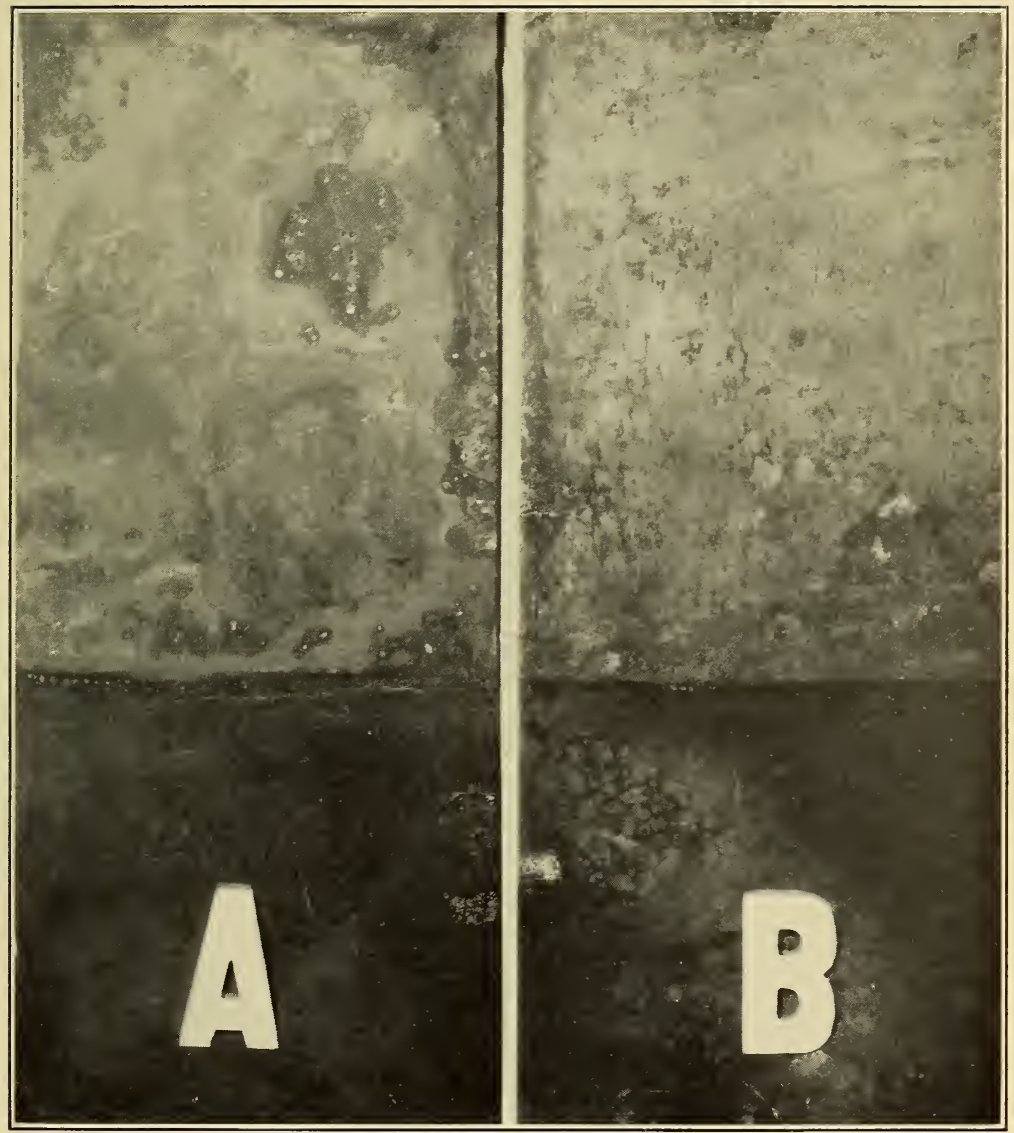

FIGURE 8.-Same as Figure $\%$, but after 200 hours accelerated weathering at $50^{\circ} \mathrm{C} . \quad \times 0.7$ 
B. S. Journal of Research, RP422

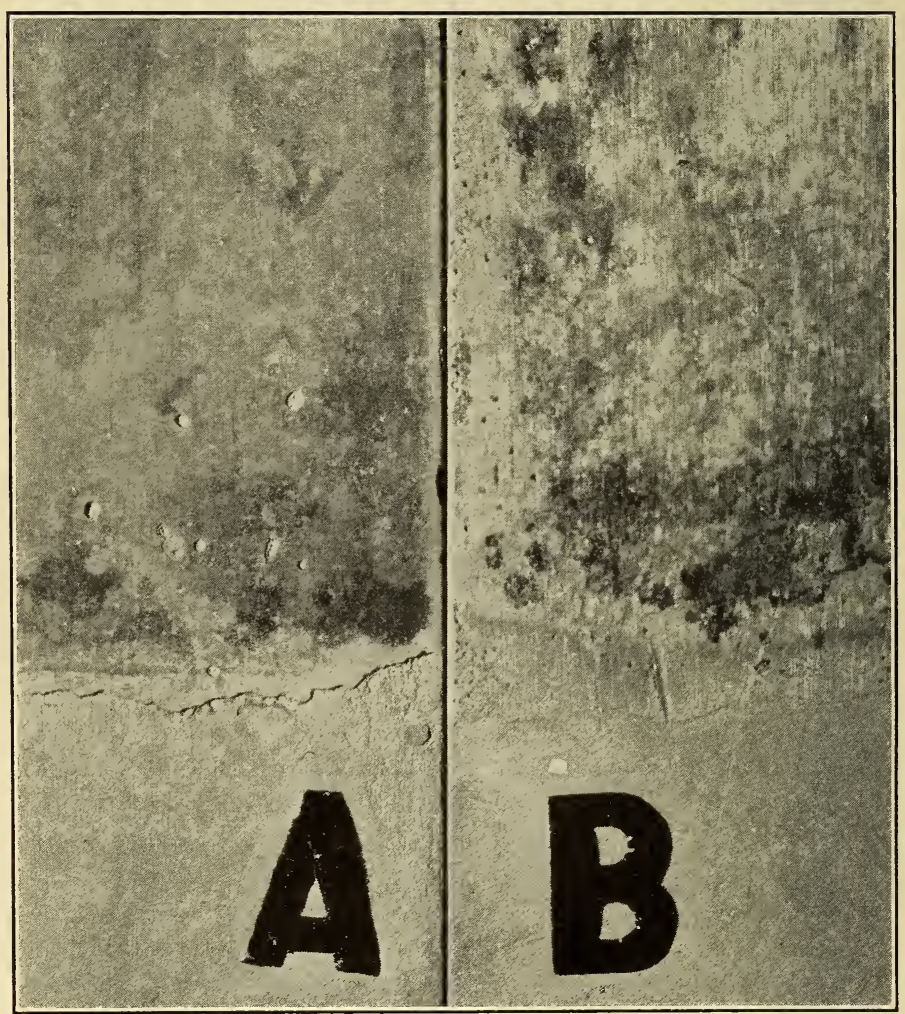

FIgURe 9.-Same as Figure 8, but after pickling. $\quad \times 3.7$ 
B. S. Journal of Research, RP422

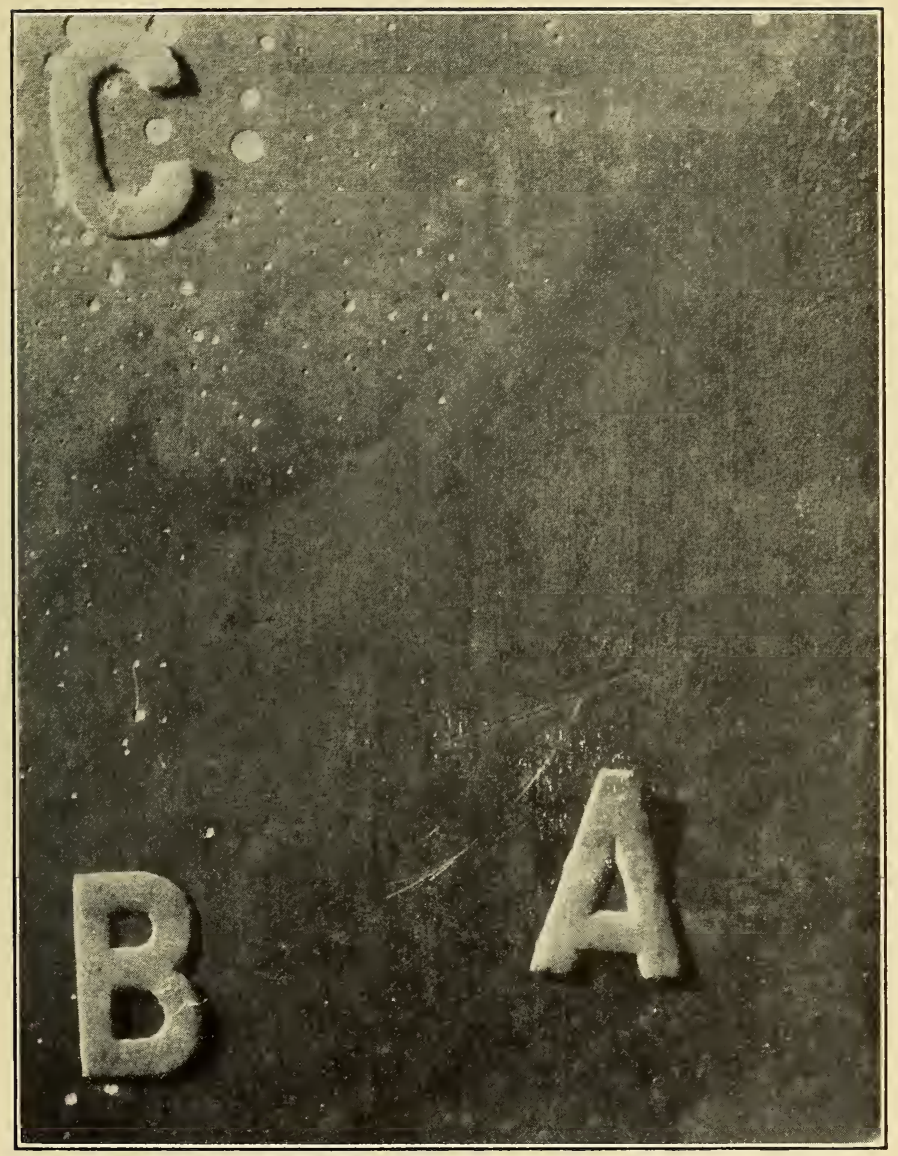

FIgURE 10.-Phases on acceleratedly weathered soldered copper $A$, Dull gray with no pits; $B$, blue gray with a few pits; $C$, white gray with many pits. 
B. S. Journal of Research, RP422

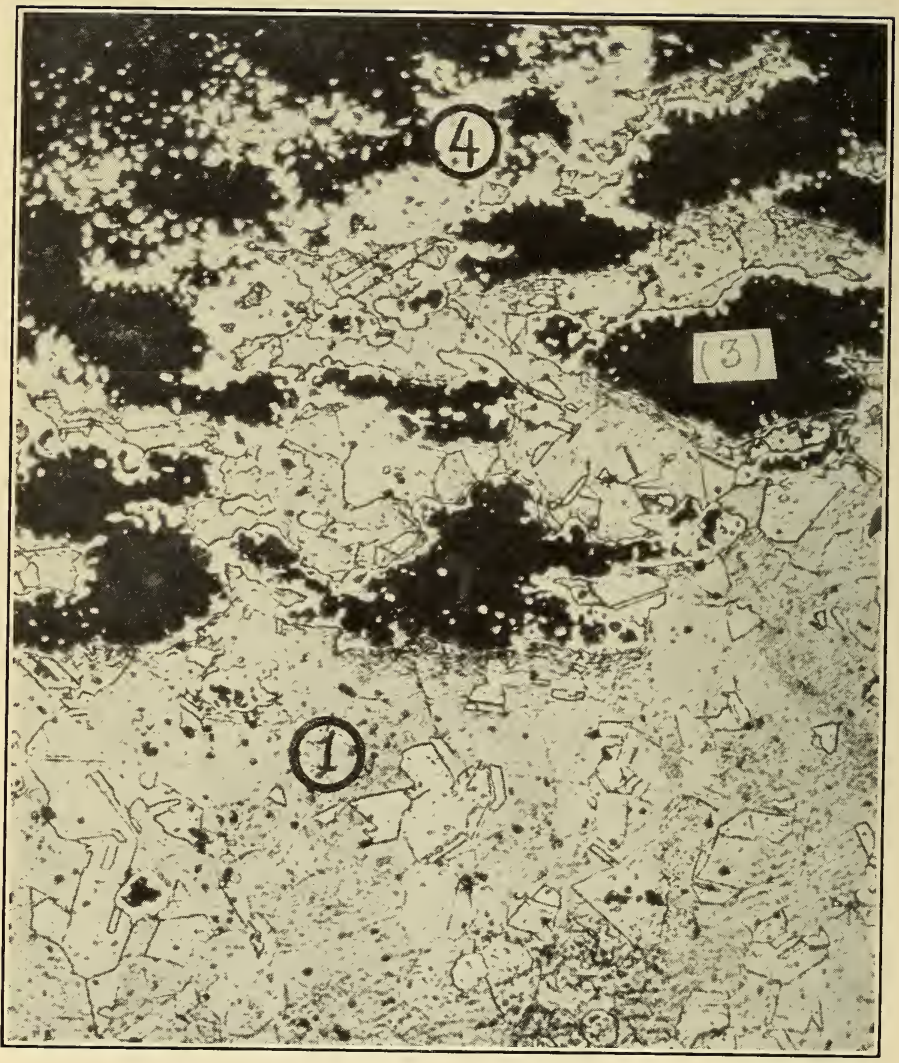

FIgure 11.-Oblique section of sheet copper soldered at $270^{\circ} \mathrm{C}$. $\times 500$

Etchant: $\mathrm{NH}_{4} \mathrm{OH}+\mathrm{H}_{2} \mathrm{O}_{2}$. 1, Sheet copper base; 3, unchanged solder; 4, $\epsilon^{\prime}$ phase. 
B. S. Journal of Research, RP422

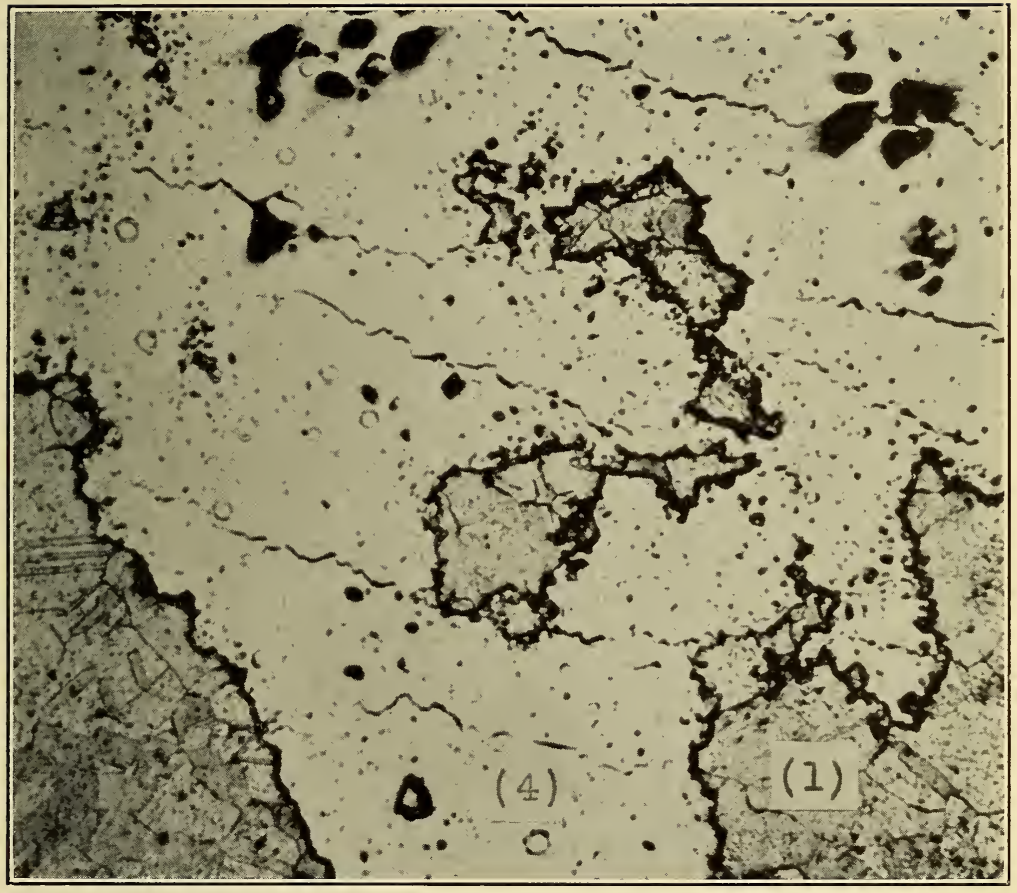

FigdRE 12.-Oblique section of sheet copper soldered at $270^{\circ} \mathrm{C}$. and heated to $500^{\circ}$ C. for 3 hours. $\times 500$

Etchant: $\mathrm{NH}_{4} \mathrm{OH}+\mathrm{H}_{2} \mathrm{O}_{2}$. 1 , Sheet copper base; 4 , copper-tin alloys. 


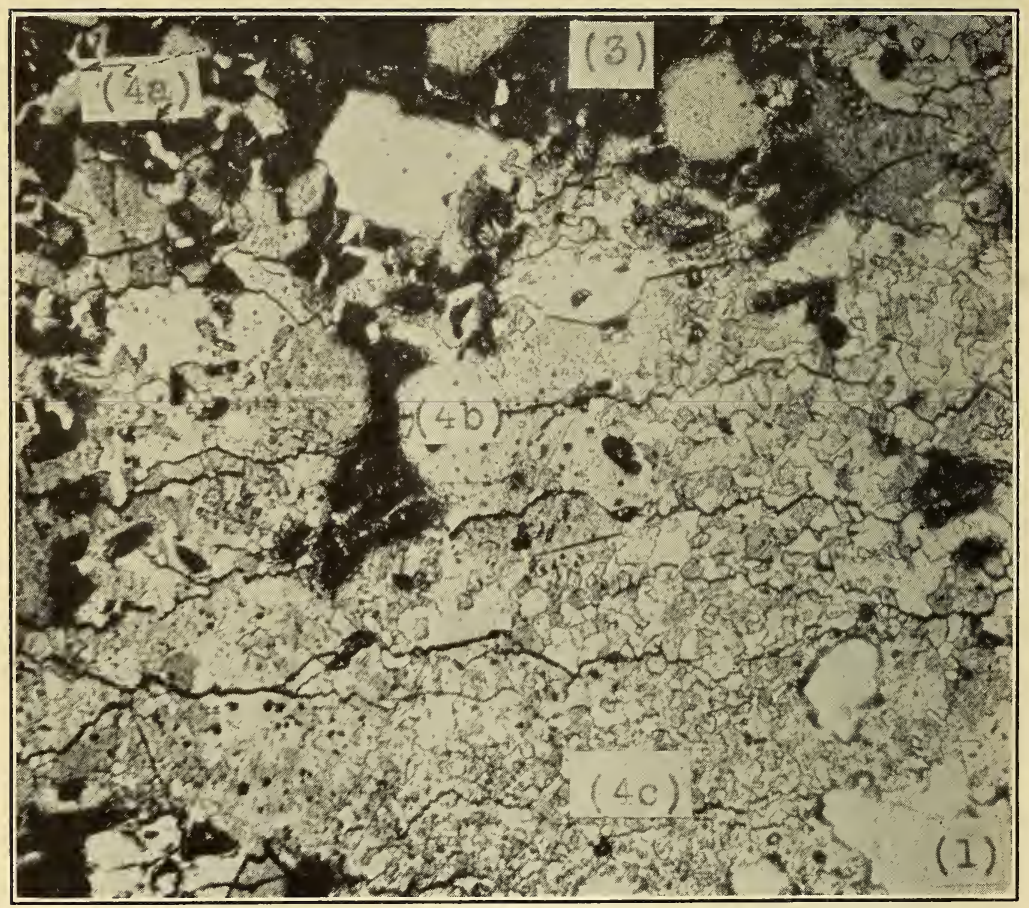

FIgURE 13.-Same as Figure 12, but after prolonged etching with $\mathrm{Fe} \mathrm{e}_{3} \mathrm{Cl} . \mathrm{HCl}$ and nitric acid dip. $\times 200$

1 , Sheet copper base; 3 , unchanged solder; $4 a$, bright areas of $\epsilon^{\prime}$ phase; $4 b, \eta$ phase; $4 c, \delta$ phase. 
there is noticeable the etching of copper adjacent to solder in areas where the flow of rain water was considerable.

\section{PITTING OF SOLDERED COPPER}

Pitting of soldered copper is another example of the pitting of copper which has been coated with a metallic alloy containing tin. The usual place to find such pits is the uppermost ridge of the seamthe place that would be the first to be touched by the soldering iron, that receives the wear and tear, and that would be expected to have the thinnest coating of solder. The specimens of hand-tinned copper which were judged to have the thinnest coating also suffered the most corrosion. Pits formed during the soldering process are akin to blowholes. They are those pits which have patina-covered copper on the bottom.

Nightingale (19) and Beij (20) and others have shown that the strongest soldered joint has but little solder between the copper members and that piling up heavy wide bands of solder on flat lock seams to increase their strength is not worth while. However, from the point of view of corrosion resistance, a moderate amount of solder which completely covers the copper-tin alloys is beneficial in preventing the pitting of copper. It does not seem possible to prevent seam corrosion by such a procedure.

\section{SEAM CORROSION}

The influence of the temperature of soldering on seam corrosion which is another example of detrimental galvanic corrosion of copper by copper-tin alloys is shown by the change in the physical properties upon weathering, especially of the soldered and annealed specimens weathered for 200 hours at $50^{\circ} \mathrm{C}$. The tensile strength of one individual specimen was lowered as much as $3,000 \mathrm{lbs}$./in. ${ }^{2}$ due to accelerated weathering. The greatest change was in the number of bends needed to produce failure.

The bend test is essentially a severe fatigue test, though the results obtained from such tests are empirical in nature and difficult to apply to everyday service. When copper is used for roofing purposes it may be subjected to repeated bending through small angles, especially if it is so anchored that the ends of a long stretch can not slide, and expansion and contraction results in buckling and stressing. At points where the copper is stiffened, as by the use of solder, the bending will tend to occur at the copper-solder junction. The results given in Figure 6 show that weathering has a pronounced effect on the fatigue properties of such a joint, as measured in terms of the number of bends to produce failure, and that the weathering effect is greater the higher the temperature to which the solder is subjected. Experienced sheet-metal workers are confident that their joints will not pit and furrow. Such men advocate the use of soldering irons at low temperatures. It is a pity that the poor workmanship of novices is not revealed before a whole decade passes. It is probably their work that accounts for seam corrosion occurring on a small portion of some roofs, the soldering on the other portions being done by experienced men and showing no signs of corrosion at the end of a decade. The use of eutectic solder which would permit soldering at lower temperatures might be beneficial. 


\section{FLUXES}

The matter of fluxes is still a problem. Though flux is not responsible for the seam corrosion nor for the pitting of copper covered with tin-bearing metals, carelessness in handling the flux can cause damage. Drops of any solution, such as sodium chloride or "killed" acid flux, which can form insoluble copper salts, will cause pitting of the copper if allowed to remain on it (21). For instance, drops of sodium-chloride solutions whose concentration is $N / 100$ or stronger, formed in their center a deposit of insoluble basic copper chloride when allowed to stand on copper under conditions which prevented evaporation. The maximum depth of pitting measured in tests extending over five weeks was found to have been reached in the third to fourth week and was of the order of 0.004 inch $(0.01 \mathrm{~cm})$. Some scratches which passed through this copper-chloride deposit were enlarged, usually by a continuous series of pits along them. Heating copper to $100^{\circ} \mathrm{C}$. for an hour, causing the formation of oxide film, resulted in wider and deeper pits being formed under drops of salt solution. A porous red deposit, believed to be cuprous oxide, was found underneath the green deposit in the pitted areas.

When solutions of zinc chloride, which are representative of flux, were used instead of sodium chloride solutions, the same phenomenon occurred, only the copper was pitted to a greater degree. A concentrated solution of zinc chloride was more destructive than a dilute one. Laboratory experiments showed that improperly killed flux was more destructive to copper than zinc chloride solutions.

These deposits under which pitting occurred were not removable by a strong stream of water. It is therefore unwise to be careless when using killed acid flux and depend upon rain to wash any spilt or excess flux from the roof. This is especially so during summer months when much repair work is done on roofs, because of the possibility of extended periods of drought, during which the pitting may get started and the adherent films will not be washed away.

\section{CONCLUSIONS}

Accelerated weathering tests with a humid-gas mixture of 1 per cent $\mathrm{SO}_{2}, 5$ per cent $\mathrm{CO}_{2}, 94$ per cent air at temperatures above $50^{\circ} \mathrm{C}$., were made, in which were duplicated the pitting of tinned copper and the furrowing of copper at a copper-solder junction such as occasionally occurs in copper-roofing material during service. The phenomenon is associated with the formation of copper-tin alloys at the junction of the copper with the tin or solder. These alloy layers are brittle, and cracks are easily formed; the exposed copper forms the anode of a galvanic cell with the alloy in the presence of suitable solutions and is corroded. The higher the temperature used for tinning or soldering the greater is the tendency for pits and furrows to form by subsequent corrosion. The prevention of the formation of such alloys removes the tendency of the soldered copper to pit and to furrow.

The effect of seam corrosion is to reduce the strength of soldered joints and to impair markedly the fatigue properties of the copper as measured in terms of the number of bends required to produce failure.

Spilt flux, if left in place, causes pitting of copper. This pitting occurs under very adherent deposits of copper salts which are not 
removable by water. The presence of thin oxide films on copper brings about deeper pitting. In such cases, when sodium-chloride solutions are used, porous cuprous-oxide deposits are found under the layer of copper salts which causes the pitting.

\section{ACKNOWLEDGMENTS}

This work could not have been carried out without the full cooperation of all members of the metallurgical division of the Bureau of Standards, especially of E. C. Groesbeck. H. H. Walkup built the new accelerated weathering apparatus and calibrated the flow meters. Thanks are due the Copper and Brass Research Association and its member companies for their material assistance and interest in the work.

\section{SELECTED BIBLIOGRAPHY}

1. P. D. Merica, Structure of the Coating on Tinned Sheet Copper in Relation to a Specific Cause of Corrosion, B. S. Tech. Paper No. 90, 1917.

2. Tin-Copper Equilibrium Diagram, National Metals Handbook, Am. Soc. Steel Treating, p. 771, 1930; Metal Progress, vol. 18, No. 3, p. 114, September, 1930.

3. A. C. Dafton and F. L. Brady, Corrosion of Copper Pipes, Nature, vol. 20, p. $367,1927$.

4. U. R. Evans, Corrosion of Metals at Joints and Crevices, J. Roy. Soc. Arts, vol. 75, p. $544,1927$.

5. T. B. Crow, Some Properties of Soft Soldered Joints, J. Soc. Chem. Ind., vol. 43, p. 65T, 1924. Some Experiments on the Soft Soldering of Copper, J. Inst. Met., vol. 35 , No. 1 , p. $55,1926$.

6. J. Weiss, Introduction to the Study of Metallic Cementation, Revue de Metallurgie, vol. 21, p. 18, 1924.

7. C. T. Heycock and F. H. Neville, The Constitution of the Copper-Tin Series of Alloys, Phil. Trans. Roy. Soc. Series A, vol. 22, p. 1, 1904.

8. E. C. Groesbeck and W. A. Tucker, Accelerated Laboratory Corrosion Test Methods for Zinc Coated Steel, B. S. Jour. Research, vol. 1, p. 255, 1928.

9. H. S. Rawdon, A. I. Krynitsky, and W. H. Finkeldey, Types of Apparatus Used in Testing the Corrodibility of Metals, Proc. A. S. T. M., vol. 24, p. $717,1924$.

10. H. S. Rawdon, Corrosion Embrittlement of Duralumin, II. Accelerated Corrosion Tests and the Behavior of High Strength Aluminum Alloys of Different Compositions. Tech. Note No. 283, N. A. C. A., April, 1928.

11. K. H. Beij, Corrosion of Open-Valley Flashings, B. S. Jour. Research, vol. 3, p. 937, 1929.

12. W. H.J. Vernon, A Laboratory Study of the Atmospheric Corrosion of Copper, Trans. Faraday Soc., vol. 27, p. 255, 1931. Open Air Corrosion of Copper, J. Inst. Met., vol. 42, p. 181, 1929; vol. 44, p. 389, 1930.

13. W. H. J. Vernon, Atmospheric Corrosion of Metals, Trans. Faraday Soc., vol. 19 , p. 839,1924 .

14. J. C. Hudson, Atmospheric Corrosion of Metals, Trans. Faraday Soc., vol. 25, p. 177,1929 .

15. J. C. Hudson, Effects of Two Years' Atmospheric Exposure in the Breaking Load of Hard Drawn Nonferrous Wires, J. Inst. Metals, vol. 44, p. 409, 1930.

16. J. N. Friend, Relative Corrodibilities of Ferrous Alloys and Nonferrous Metals and Alloys, J. Inst. Met., vol. 42, p. 149, 1929.

17. T. Appleton, Tin and Copper Roofing, J. Soc. of Constructors of Federal Bldgs., vol. 4 , p. $183,1913$.

18. E. G. Schweig, Roofing Comment, J. Soc. of Constructors of Federal Bldgs., vol. 4, p. 402, 1913.

19. S. J. Nightingale, The Joining of Metals, Brit. Non-Fer. Metals Res. Assoc., Res. Rep. No. C234/214, December, 1929.

20. K. H. Beij, Seams for Copper Roofing, B. S. Jour. Research, vol. 5, p. 585, 1930.

21. U. R. Evans, The Corrosion of Metals, Ed. Arnold \& Co., 1924.

Washington, December 30, 1931. 